\title{
Változásfolyamatok a magyarok és ukránok által lakott kárpátaljai Izsnyéte közösségében
}

\author{
DOSZPOLY ROLAND ${ }^{1}$
}

\begin{abstract}
ABSZTRAKT
Kutatásaimat a kárpátaljai Izsnyétén 2012-ben kezdtem antropológiai kutatócsoporttal. Kezdetben a lokális település együttélési mechanizmusaira, az ott élő etnikumok kulturális sajátosságaira voltunk kíváncsiak, de a háborús helyzet miatt hamarabb abba kellett hagynunk empirikus kutatásainkat 2015 eloott. 2017-ben, doktoranduszként folytattam empirikus kutatásaimat Izsnyétén, ahol a magyarok abszolút többséget képviselnek az államalkotó ukrán etnikummal szemben. Az alapvető kutatási koncepció az volt, hogy olyan határhoz közel eső lokális települést válasszak, ahol kettô, vagy három eltérő etnikum él együtt évtizedek óta. Tanulmányomban az etnicitás termelődésének folyamatát vizsgálom, valamint a településen élő etnikumok egymásról alkotott képét és változásait, valamint egymáshoz való alkalmazkodási folyamatait korábbi kutatások adataival összehasonlítva, reflektálva a változásokra, föként az asszimiláció tükrében. Már a 2012-es kutatások eredményei is térbeli izolációt mutattak, sok esetben a disszimiláció volt tapasztalható az együtt élő etnikumok között, azonban számos más tényezó és aspektus az elmúlt években eltérö, változatos folyamatokat idézett elő.
\end{abstract}

KULCSSZAVAK: asszimiláció, etnikum, Kárpátalja, antropológia, disszimiláció, változás

\section{ABSTRACT \\ Processes of change in the Hungarian and Ukrainian Community in Izsnyéte, Transcarpathia}

I started my research in Izsnyéte, Transcarpathia, in 2012 with an anthropological research group. Initially, we were curious about the coexistence mechanisms of the local settlement, the cultural peculiarities of the ethnic groups living there, but due to the war situation, we had to stop our empirical research sooner before 2015. In 2017, as a doctoral student, I continued my empirical research in Izsnyéte, where Hungarians represent an absolute majority against the state-forming Ukrainian ethnic group. The basic research concept was to choose a local settlement close to the border where two or three different ethnicities have lived together for decades. In my study, I examine the process of ethnicity production and the processes of image and change of the living ethnicities of the settlement and their applicability to each other in comparison with the data of previous research, reflecting on the changes, mainly in the light of assimilation. Already the results of the 2012 research showed spatial isolation, in many cases

\footnotetext{
${ }^{1}$ Debreceni Egyetem, Történelmi és Néprajzi Doktori Iskola, e-mail: doszroli@gmail.com
} 


\section{TANULMÁNY}

dissimilation was experienced among coexisting ethnicities, but with many other factors and aspects several years later, it caused diverse processes.

KEYWORDS: assimilation, ethnicity, Transcarpathia, anthropology, dissimilation, change

\section{Bevezetés}

Tanulmányomban az etnikumok egymásról formált képének alakulását és helyzetét vizsgálom egy lokális közösségben, a kárpátaljai Izsnyétén, ahol ukránok, magyarok és romák élnek együtt. A kutatási hagyományok tükrében a vizsgált magyar-szlovák-ukrán hármashatár problematikája, azaz a határ pontos meghatározása meglehetősen nehézkes. A politikai térszerkezet struktúráját, illetve annak rétegződését áttekintve ugyanis azt a következtetést vonhatjuk le, hogy NUTS 2 szintű entitások tekintetében Ukrajnában nincs belső egységhatár a funkcionális régión belül (Pikler 2016). A funkcionális régió teljes területe Ukrajnában Kárpátalja régióhoz tartozik. Mivel a NUTS 2 szintű entitások a strukturális alapok támogatásainak fő célterületei a kohéziós politikán belül, sőt a szomszédságpolitikán belül is, ezért nem jelentőség nélküli, hogy egy funkcionális terület egy NUTS 2-es entitás részét képezi-e, vagy pedig e fejlesztési régiókat elválasztó belső határvonal metszi át a funkcionális területet, mint Magyarország esetében. A tanulmány egyetlen települése tartozik az említett hármashatár vizsgálat körébe. A célterület kiválasztásánál fontos szempont volt, hogy minél több kiválasztott település a hármas határnál, vagy a közelében legyen. Ugyanakkor a megközelítésük és a hasonló történelmi háttér is egy fontos szempont volt a számos, társadalomtudományi fontosságú okokkal alátámasztott kiválasztás mellett.

\section{Elméleti felvezetés}

A határ menti településeken végzett kutatások az asszimilációs és disszimilációs elméletekből indulnak ki. Első körben vizsgálom a térségben lezajlott asszimilációs, illetve disszimilációs folyamatokat a különböző etnikumok körében településenként, majd azt nézem meg, hogy milyen hatásai voltak e folyamatoknak a kilencvenes évektől napjainkig. A terepmunka egy külhoni terep együttesen zajlott le Kárpátalján, ahol párhuzamosan vizsgáltam az asszimilációs folyamatokat is. Előzőekben feltételeztem tehát, hogy az általam vizsgált eltérő etnikus sajátosságok az asszimilációs folyamatok termékei, hatáskövetkezményei, melyeknek különböző formái, népcsoportokként eltérő változatai léteztek és léteznek.

A néprajzi és antropológiai indíttatású tanulmányokat kizárólag a társadalomtudományi területeken elterjedt módszer határozza meg, ahol nem beszélhetünk fizikai határokról. Itt a kulturális, fizikailag nem jelenlévő határokról beszélhetünk. Mivel jelen kutatásban is több etnikum közötti kulturális határok feltérképezése is 


\section{TANULMÁNY}

cél, így az antropológiai módszert érdemes közelről megvizsgálni. Az egymás mellett élésnek, a különböző etnikumok egy településen való együttélésének nagyon szerteágazó típusai létezhetnek. Biczó Gábor például egyensúlyhelyzetről ír elméletében. Romániában, a szilágysági Tövishát terep együttesén végzett terepmunka során vált nyilvánvalóvá Biczó Gábor számára, hogy a vizsgált színtér együttélési mechanizmusai az egyensúlyi helyzet elmélettel magyarázható (Biczó - Kotics 2013). Az egyensúlyi helyzet formalista elmélete a múlt század közepén pszichológiai alapokon kidolgozott strukturális egyensúlyelméletével vált népszerűvé. Később az 1980-as években biológiai alapokon fejlesztették tovább a modellt.

A modell társadalomtudományokban betöltött lényege, hogy különösen a társadalmi rendszereket alkotó alapegység (elem), az ember működése a környezet hatáskövetkezményeinek függvényében értelmezhető. Ebben az összefüggésben a társadalmi valóság minden szegmense, beleértve a lokális társadalmi közösséget, egyszerre írható le önmagát a működésben folyamatosan újratermelő és környezetével kölcsönhatásban újrateremtett rendszerként. Nevezhetjük ezt a modellt békés együttélési modellnek is, leegyszerűsítve. Az egyensúlyhelyzet jelenség olyan településen/településeken figyelhető meg, ahol - mint a tövisháti kutatás esetében is - az etnikai arányok másfél évszázadon keresztül szinte alig változtak. Ennek a modellnek az esetében nem lehetséges asszimilációs, vagy akkulturációs jelenségekről beszélni. Hogy a modell beilleszthető-e a saját kutatásomba, vagy más, akár asszimilációs folyamatokról beszélhetünk-e, kérdéses, de már a felderítő jellegű kutatások során sem a „békés”, konfliktusmentes helyzetről vagy egyensúlyról árulkodtak a helyi történések. Jóllehet az évek múlásának folyamatában ez sokkal jobban megfigyelhető. Mindenesetre meglehet, hogy a különböző települések lakóinak együttélése más-más modellel is magyarázhatók, valamint az etnikai arányok és annak változásai tükrében ez a kutatási eredmények összefoglalójában már jól láthatóvá válik.

Az etnikai együttélési viszonyokat a rendszerváltás utáni időszaktól napjainkig vizsgálom a kiválasztott határ menti, vagy határhoz közel eső településeken. A rendszerváltás óta különböző nemzet egységesítési, asszimilációs, illetve disszimilációs folyamatok zajlottak le Kárpátalján. Az asszimiláció mint társadalomtudományi fogalom, minden esetben valamilyen változást jelent, egy adott népcsoport vagy etnikum életében bekövetkező szociokulturális változást. A változás nem egyidejűleg és nem egy helyen megy végbe, a legtöbb esetben hosszú folyamat és kiterjed az adott közösség életének minden területére. A változásfolyamatnak pedig következményei, hatásai vannak. Az asszimiláció a szociokulturális változások megnevezésére szolgál. Jelentését átszövik a társadalmi lét etnikai, nyelvi, vallási és kulturális sajátosságai, valamint az egyéni és csoportos, identikus, mentális és intencionális változásai. A kulturális asszimiláció alatt azt a folyamatot értjük, amely során az egyik etnikum vagy közösség fokozatosan átveszi egy másik etnikum kultúrájának elemeit (Karády 1997). Többek között olyan elemeket, mint a nyelv, a vallás, a viselkedési mintázat stb. A kulturális asszimiláció végső eredménye, hogy a korábban különböző etnikai 


\section{TANULMÁNY}

csoportokat már nem tudjuk viselkedésük, megjelenésük vagy értékrendjük alapján azonosítani. Az asszimilációnak négy klasszikus modellje létezik (Biczó 2004: 55). Az első, amikor a befogadó nép az asszimilálódó többség reprezentációja, és a másik nép az idegen asszimilálódó kisebbség képviselője. Klasszikus példák erre a történelemből, amikor különböző, az európai vallásoktól lényegesen eltérő vallási népeket - iszlám vallásúakat például - próbáltak asszimilálni keresztény közösségekben, Magyarországon is.

A második asszimilációs típus már gyakoribb jelenség napjainkban is, ennek neve a befogadó asszimiláló kisebbség és az idegen asszimilálódó többség típusa. Számos ilyen példa létezett az Osztrák-Magyar Monarchia felbomlását követő évekből, valamint a 19. század második felétől, amikor a többségi idegen közösség egy kisebbségben élő - például roma kisebbség - közösség normáit kezdte követni, annak feltételrendszeréhez kívánt alkalmazkodni. A harmadik asszimilációs típust szimmetrikus viszonyúnak is nevezhetjük, hiszen itt mindkét fél, a befogadó és az idegen közösség szoros viszonyáról és az asszimiláns intenzív - nyelvi akadályoktól is mentes asszimilációjáról. Számos ilyen példa angolszász területeken vagy francia nyelvterületeken ment végbe a második világháború előtti időszakban. Az asszimiláció negyedik típusa vagy modellje egy strukturális altípus, egyfajta viszony, mely szintén gyakori példa volt például a Kárpát-medencében, ahol a honfoglaló magyarok a szláv kisebbségi népeket asszimilálták.

A disszimiláció az asszimiláció reciprokjaként is magyarázható. Az asszimilációnak több fajtája és településenként, közösségenként változó formái léteznek. Ugyanakkor nem minden asszimilációt tekinthetünk teljesnek, végbementnek, a folyamatnak van egy eltérő, más irányú mozgása is, jelesül a disszimilációra reflektálva. Yinger írta le a disszimiláció fogalmát az asszimiláció tükrében (Yinger 1976: 197216). E fogalmat is lényeges használni az együttélési modellek tekintetében. Yinger asszimilációelméletébe beépíti a disszimiláció, az asszimiláció kölcsönös, fordított fogalmát, mely a csoporton belüli különbségek fennmaradását és megerősödését fejezi ki. Recens példa a mai, 21. századi kistelepüléseken, határ menti településeken, ahol több etnikum él együtt, például Kárpátalja határ menti településein is. Ilyen esetben az asszimiláció nem megy végbe, nem azonosulnak az adott etnikumok több életterületen, hanem az eltérő szokások, a nyelv stb. egyre jobban különböznek, a különbözőségek felerősödnek, melyek később konfliktusokat generálhatnak és az együttélést nehezítik meg. Az etnikumok eltávolodnak egymástól, teljes elkülönülés megy végbe. A vizsgált területeken is számos példája lesz e disszimilációs modellnek.

A komplementaritás szintén antropológiai alapfogalom, elmélet, az asszimilációs folyamatok kapcsán tűnik fel. A különböző antropológiai, sőt gazdasági antropológiai műveknél szinte mindig összetalálkozunk vele például, ha a generációk közötti gazdasági tevékenységeket, vagy a habitust nézzük. Kotics József jeles képviselője a témának. Kotics különböző gazdaságantropológiai munkáiban komplementaritást 


\section{TANULMÁNY}

vél felfedezni kisközösségek gazdálkodói habitusában, mely a generációk közt, illetve etnikumok közt is megjelenik. Megjelenik egyfajta „komplementarizáció, amely nem a szembenállásra épül” az etnikumok között, hanem az egymás segítésére, egymás előnyös oldalainak kihasználására, kölcsönös kommunikatív és gyakorlati munkavégzésre (Biczó - Kotics 2013: 40).

Együtt élő vagy egymás mellett szorosan élő és egymástól függő közösségek tekintetében a néprajz és az antropológia gyakran alkalmazza az asszimilációs, illetve az akkulturációs elméleteket. Charlotte Seymour Smith meghatározásában például az asszimiláció az akkulturációs folyamat egyik következménye, mikor egy kisebb vagy alárendelt csoport felszívódik egy nagyobb vagy domináns csoportban, és kulturális értelemben megkülönböztethetetlenné válik (Smith 1993). A definíció az asszimiláció kérdését az akkulturáció származtatott következményeként, mint állapotot mutatja be, vagyis a teljes kultúraváltás eredményeként bekövetkező helyzet leírására alkalmas fogalomként. Sőt az asszimiláció koncepciója a modern antropológiában széles körben megkérdőjelezett, hisz a legtöbb szerző az eltérő szociokulturális rendszerek között megvalósuló érintkezés, a kulturális csere és a társadalmi dominancia különböző dimenzióit érintő vizsgálatkor a sokkal körültekintőbb eljárás mellett érvel.

A magyarázó modellek tekintetében szó kell, hogy essen a hibriditásról is. A hibriditás az a jelenség, amikor az egyes kultúrák jegyei egymással keveredve jelennek meg a posztkolonialitás közegében. Niedermüller Péter a posztkoloniális szemléletmódot igyekezett lefordítani és a közép-európai nemzetállamok közegében alkalmazni. Nézete szerint „A kreolizáció és a hibridizáció fogalmak arra mutatnak tehát rá, hogy a modernitásnak az az oppozíciója, amely a kulturális különbségek megörzését a kulturális asszimilációval állította szembe, nem vagy csak egyre kevésbé képes a késő modern társadalmak konfliktusainak kezelésére. Mindebböl következöen az etnicitást, az etnikai és a nemzeti identitást sem lehet egyszerüen a múltból, a kulturális hagyományok összefüggésében levezetni, s nem lehet azt valami természetesnek, adottnak és megváltoztathatatlannak tekinteni." (Niedermüller 1999: 105-120) A különböző magyarázó modellek és elméletek tekintetében mélyebben megérthető a vizsgált terepegyüttes együttélési helyzete/helyzetei, ez által könnyebben beilleszthető valamelyik modell a saját kutatásba.

A magyar-roma együttélés magyarországi szakirodalmában régóta fontos téma a jövedelmi, munkaerőpiaci egyenlőtlenség, valamint a különböző etnikai kategóriák témaköre. Szuhay Péter számos esetben vizsgálta a magyar-roma együttélést a megélhetési stratégiák tükrében (Szuhay 1999). A tanulmány azonban elsősorban a magyar-ukrán viszonyokat elemzi. A kutatói érdeklődés sokszor nélkülözi az etnikumok közötti kapcsolatok leírását szolgáló hagyományos értelmezési modellek - mint például az asszimiláció - használatát, értelmezését az etnikumközi viszonyok értelmezésénél az utóbbi időkben (Borbély 2013). A magyar-roma asszimilációs fo- 


\section{TANULMÁNY}

lyamatoknak külön részfejezetet szentelek, a roma etnikum többi etnikummal való kapcsolatát, megélhetési stratégiáit egy külön fejezetben részletezem.

Meglehet, az elsősorban néprajzi és antropológiai indíttatású kutatások sokkal inkább vizsgálódnak a különböző értelmezési modellek segítségével, mint anélkül. Az etnikai - ezen belül a magyar-roma - együttélést vizsgáló hazai szociológiai, antropológia vizsgálatokban elsősorban a csoportközi differenciáló tényezők és konfliktusok, nem pedig a stabil együttélési helyzetek, pontosabban az azokat elősegítő egyensúlyteremtő technikák, társadalmi gyakorlatok álltak az érdeklődés középpontjában (Biczó - Kotics 2013). E vállalkozás azonban elsősorban az együttélési helyzeteket vizsgálja mélyebb összefüggéseiben, nem a különböző etnikai konfliktusokat egyfajta recens kutatásként, írásként.

A szöveg megjelenő problémákat és a helyi viszonyokat szakmai, teoretikusabb szinten vizsgálom meg mikroperspektívában a kortárs asszimilációkutatások fényében. Általánosságban elmondható az is, hogy asszimilálódni annyit tesz, mint elsajátítani egy másik, a sajáttól eltérő életvilág szabályait, értékkészletét. A befogadó csoportba való maradéktalan beolvadás feltételezi a nyelv, a szokások, a közösség történelmének, hagyományainak megismerését is. Kezdetben, a 19. század elején is - például a vizsgált bodrogközi területen is - tapasztalhatók voltak asszimilációs törekvések, tehát nyelvi, szokásbeli, értékrendbeli szinteken. Mint az az asszimiláció latin eredetéből ismeretes: az asszimilálódásban az utánzásnak nagy szerepe van. Az utánzás az asszimiláció formai vagy a közvetlenül átvehető külsődleges feltételek elsajátításának eszköze. Azonban az asszimilációt társadalomtudományi szemszögből nem tekinthetjük csupán hasonulásnak, vagy a másik etnikum, népcsoport másolásának, utánzásának, hiszen ahol asszimilációs folyamatról beszélünk, ott valamiféle befogadás is létrejön, tehát az egyik nép befogadó szándékú a másik közösséggel szemben (Biczó 2004).

Tanulmányomban az etnicitás termelődésének folyamatában kívánom vizsgálni az etnikumok egymásról formált képének alakulását és változásait egy lokális közösségben, ahol cigányok, magyarok és egy harmadik, államalkotó nép él együtt, településtől függően. Vagyis az asszimilációs folyamatok közvetlen következményeit, hatásait vizsgálom. Azokat a jelenségeket, melyek az asszimilációs folyamatok révén alakultak át vagy változtak meg teljes mértékben. Ilyen jelenségek az eltérő megélhetési stratégiák. A kulturális különbségek társadalmi szerveződéseként felfogott etnicitás vizsgálatakor Fredrik Barthoz (1996) hasonlóan a kulturális határoknak szentelek nagyobb figyelmet, s nem a határokon belül található kulturális anyagnak. E megközelítés a csoportoknak önmagukat körülhatároló és a határokat fenntartó, állandóan újratermelő gyakorlatára helyezi a hangsúlyt. Vizsgálom tehát azt a kérdéskört is, hogy a vizsgált határmenti szlovák településeken az 1990-es változásokat követően az eltérő etnikumok között korábban kialakult viszonyok, valamint az egymásról formált képük milyen változási folyamatokon ment át. 


\section{TANULMÁNY}

Az 1970-es évektől az etnikai kutatások diszciplináris elkülönülésének, autonóm tudásterületté válásának egyik fontos - s talán kevésbé problémás - következménye volt, hogy az etnikai különbségtétel és a hozzá kapcsolódó bizonyos diszkreditáló mechanizmusok (előítéletesség, diszkrimináció, hátrányos megkülönböztetés, szegregáció, hatalmi alárendelés) vizsgálata kikerült a hierarchiateremtő gyakorlatok átfogó és komplex rendszerének elemzési köréből.

A közgondolkodásban és a szakmai közvéleményben is széles körben elterjedt az a nézet, hogy az etnikai különbségtétel és azt kísérő szélsőségesebb megnyilvánulások (etnocentrizmus, nacionalizmus, xenofóbia) a személy- és csoportközi együttélést hosszú távon „veszélyeztető” vagy legalábbis az etnikai együttélést megnehezítő, magas konfliktuspotenciállal rendelkező faktorok. Az etnikai különbségtételre különböző példák a vizsgált színtereken is előfordulnak. A magyar-roma együttélést egy külön fejezetben vizsgálom, főként a felvidéki asszimiláció kapcsán.

Az etnikai diszkrimináció és az etnikumközi kapcsolatokban megfigyelhető aláés fölérendeltségi viszonyok - az együttélésben érdekelt felek szempontjából - nem normasértő, hanem éppen ellenkezőleg, normakövető magatartások: a helyi, falusi társadalomban a hagyománytapasztalat szerves részét képezik. A hatalmi egyenlőtlenségek ezek szerint nem a lokális közösség múködési zavarait (anomáliáit), hanem sokkal inkább a változásokkal szemben megnyilvánuló ellenálló képességét és stabilitását jelző rendszerelemek.

A tanulmány olyan interetnikus alaphelyzeteket mutat be, amelyben az aszimmetrikus etnikumközi kapcsolatok történeti, azaz (időben) tartósan fennálló, stabil képződménynek tűnnek. A vizsgált településen, a kárpátaljai Izsnyétén például több generáció óta élnek együtt ukránok, magyarok és cigányok, a közöttük lévő feudális eredetű, hierarchikus gazdasági, társadalmi kapcsolatok azonban - látható módon nem vezettek etnikai konfliktusok kialakulásához. A szinkronikus kutatás azonban egy más ívű eredményre enged következtetni az etnikumok között. Mi lehet ennek az oka? Melyek azok a lokális mechanizmusok, amelyek az aszimmetrikus etnikumközi helyzetekben csökkentik az etnikai együttélést tartósan destabilizáló gazdasági, társadalmi, hatalmi egyenlőtlenségeket? Kérdés továbbá, hogy milyen reaktív cselekvések, beszédszituációk, kulturális praxisok segítségével kerülik el a bipoláris etnikai együttélési helyzetek résztvevői a csoportközi vagy a csoporton belüli konfliktusokat, egyszóval hogyan stabilizálják a helyi társadalmat? Az elemzés célja, hogy az empirikus társadalomkutatás módszertani eszközeivel feltárja azokat a mikro szituációs helyzeteket és hétköznapi technikákat, amelyek az etnikai együttélés és a csoporton belüli integrációs folyamatok szempontjából meghatározók lehetnek. 


\section{TANULMÁNY}

\section{Kárpátalja északnyugati, határ menti települései}

\section{A GAZDASÁG ALAKULÁSA AZ ETNIKUMOK ÉS A TÉRFELOSZTÁS TÜKRÉBEN}

A gazdasági viszonyokra csak részben reflektálok - hiszen témám nem teljesen a gazdaságra terjed ki -, azonban fontos megemlíteni a térrendeződés és történteti múlt tekintetében néhány gazdasági változásfolyamatot, melyek a népesség átszerveződésére és az asszimilációs folyamatokra is hatással voltak vagy hatással lehettek az idők során.

Ha megvizsgáljuk Kárpátalja kezdeti gazdasági viszonyait, a régió földrajzi adottságainak előnyeit azonnal kiemelhetjük. A terület földrajzi adottságai ugyanis kiválóan szolgálták a korai Árpád-korban kialakított gyepűrendszer feltételeit. Ez a térség mezőgazdasági fejlődésének alapjait biztosította. A mai Kárpátalja sokáig elmaradott gazdasági helyzetben volt 1920 után Magyarország többi régiójához képest. A földrajzi viszonyok meglehetősen kedvezőtlenek voltak, a növénytermesztésre használható terület a Kárpátok gerincétől az Alföldre siető folyók völgyeire korlátozódott. A ruszinok nagy része falvakban élt, ahol naturális, önellátó gazdálkodást folytattak. Nagy súlya volt a gazdaságban az állattenyésztésnek, valamint a ruszinoknál nagy jelentősége volt a fakitermelésnek és a tutajozásnak (például a cigarettacsempészek körében) is. Ezen mesterségek egy része majd 70 évig fennmaradt (a közös gazdaság alatt is), a privatizáció azonban sok mindent megváltoztatott a gazdaságban.

A szinkronikus értelemben vett kutatás a mai viszonyok között kedvező földterületeket azonosít. A kolhozok felbomlása óta - az 1990-es évek után - Kárpátalján eltérő nagyságú ipari és mezőgazdasági területeket örököltek a lakók. E földterületeket ma változó mértékben és eltérő gazdasági stratégiákkal müvelik mind az ukrán, mind a magyar etnikum tagjai. Sokan eladják a földeket, de sokuknak ez jelenti a megélhetés fó alapját még ma is.

Már az 1990-es évek előtt is a kárpátaljai lakosság többsége falvakban lakott és mezőgazdálkodással foglalkozott (Baranyi 2009). A szocialista országok gazdasági stratégiájának kidolgozásába a következő főbb elérendő feladatok tartoztak: a dolgozók jólétének növelése, a társadalmi termelés gazdasági hatékonyságának fokozása és intenzifikálása, valamint a nemzetgazdaságok fokozottabb bekapcsolása a szocialista nemzetközi munkamegosztásba (Fedorenko 1984).

A kolhozrendszerben a kolhoztagok keveset kerestek, fő megélhetési forrásuk a háztáji gazdaság volt. A kolhoz rendszer legnagyobb hátránya a pazarló, gazdaságtalan módon való működése volt, tehát a lakosságot nem tudta megfelelő élelmiszermennyiséggel ellátni. Az 1980-as években a gorbacsovi reformok negatívan érintették a gazdaságokat, főleg a szőlészet és a gyümölcsborok palackozása tekintetében. Ekkoriban az országot nagy gazdasági válság sújtotta, az egyre liberalizáló törvények lehetővé tették a magángazdálkodás bizonyos formáit, így megindult a 


\section{TANULMÁNY}

szövetkezetek kooperatív átalakítása, melyen keresztül elkezdődött az állami vagyon átpumpálása magánkezekbe (Baranyi 2009).

Az 1990-es évek eleje egyértelműen a gazdasági válság időszaka volt. Felbomlott a Szovjetunió, létrejött az önálló Ukrajna. Rengeteg gyár és üzem zárt be a következő években, az emberek későn jutottak hozzá fizetésükhöz, úgynevezett hiperinfláció keletkezett a gazdaságban. A migrációs hullám növekedő tendenciát mutatott, számos családból vándoroltak át Magyarországra dolgozni, továbbá ebben az időszakban virágzott leginkább a határ menti kereskedelem és a csempészet is.

\section{NÉPESSÉGI ADATOK, ETNIKAI ÖSSZETÉTEL}

A Kárpát-medence mezorégiója, Kárpátalja a legfiatalabb magyar tájnevek egyike. Népesség-összetételét tekintve legalapvetőbb jellemzője az etnikai sokszínűség. Kárpátalja történeti sorsának alakulását számos nemzetiség határozta meg az idők folyamán, míg kialakította jelenlegi kulturális, territoriális és etnikai határait. „Önálló, autonóm életét 1918-ban kezdte, majd negyedszázadon belül három hatalmi és rendszerváltást átélve vált az egykori Szovjetunió, majd az Ukrán Köztársaság egyik sajátos hagyományú területévé." (S. Benedek 1994: 67)

Kárpátalja népessége megközelítőleg 1 és negyed millió fő, a 2001-es népszámlálás adatok alapján 1254160 fő volt, 2016-ig pedig növekedett a lakosság száma 1259000 főre. ${ }^{2}$ A etnikai arányokat tekintve a kárpátaljai magyar lakosság jelentős változásokon ment keresztül az elmúlt évtizedekben. Az 1989-es népszámlálás jelezte először a magyar számbeli csökkenését (155 711 fő), de a nem magyar nemzetiségü, ám magyar anyanyelvű lakosokkal együtt a magyar közösség száma 166 700ra emelkedett. A magyarok Kárpátalja második legnépesebb etnikai csoportját alkotják, a területen végzett utolsó 2001-es ukrán népszámlálás során 151533 magyart írtak össze (Molnár 2004). Kutatások alapján a magyarok száma fokozatosan nő.

Kárpátalja lakosságának legnagyobb részét a ruszinok alkotják. A ruszin vagy rutén nép eredetileg Volhíniában, Galíciában élt kezdetben, egy részük a 18. század közepén jelent meg a Keleti-Kárpátokban. 1989-ben 976749 ukránt számláltak. „Az ukránok aránya 1950 óta folyamatosan nö, számuk 2001-ben 1001149 föt tett ki." (Molnár 2004: 53)

\footnotetext{
${ }^{2}$ Az ukrán népszámlálás hivatalos honlapja: http://www.ukrcensus.gov.ua (2019. 10. 15.)
} 


\section{TANULMÁNY}

\section{A KÁRPÁTALJAI KUTATÁSI HELYSZÍN TELEPÜLÉSEI}

Az etnikai arányokat figyelembe véve egyértelműen kirajzolódik egy olyan vegyes etnikai lakosságú térség és régió képe, ahol az egész kárpátaljai lakosság összetételét tekintve az államalkotó ukrán etnikum van többségben a magyar kisebbséggel szemben, de ez a kisebbség-többség reláció a régió nyugati részén már teljesen más helyzetképet ad. Kárpátalja nyugati peremvidékén, azaz leginkább Beregszász, Munkács, Ungvár, Nagyszőlős járásokban ugyanis a magyarok csaknem 90 településen abszolút többséget képviselnek az államalkotó ukrán etnikum kisebbségi helyzetével szemben. Kárpátalja vegyes etnikai lakosságába tartozik még a zárt közösségú és elég kis számban élő német nép, a Fehéregyházán és környékén domináns románok, és az évszázadok óta jelenlévő cigányság, melyből Máramaros-Ugocsa területén az oláh cigányok vannak nagy számban. Bár ezen etnikumok számarányai nem relevánsak az általam vizsgált térségben és magában a kutatási koncepcióban, de érdemes megemlíteni ezen etnikumok jelenlétét is.

A legutóbbi népszámlálás adatai szerint a románok kerültek fel a dobogó legalsó fokára, megelőzve az 1989-ben még magasan előrébb álló oroszokat. A románok száma 12 év alatt 9\%-kal nőtt és meghaladja a 32 ezret. Ez a gyarapodás a természetes szaporulatnak köszönhető. Az etnikai rangsorban a negyedik helyen az oroszok állnak. 1946-tól a folyamatos betelepítések, vándormozgalmak keretében folyamatosan gyarapodott a számuk. A kárpátaljai cigányság valós számáról nincsenek megbízható adataink. Mindennek az oka, hogy sok cigány ma is magyarnak, ukránnak, szlováknak, románnak vallja magát. A legutóbbi, 2001-es népszámlálás adatai szerint arányuk 1,1\%-ot tesz ki a megye összlakosságán belül (Fodor 2003). A cigányok száma a határ menti településeken jelentős.

\section{Izsnyéte}

Kárpátalján, a magyarság döntő többsége a magyar határ közelében, határ menti településeken, nagyjából az Ungvár, Császlóc, Csongor, Izsnyéte, Dercen, Beregújfalu, Salánk, Fancsika, Csepe, Feketeardó, Gyula behatárolt területén él, illetve szigetekben és diaszpórában, elsősorban a Felső-Tiszavidéken.

Izsnyéte jelentősen magyarok által lakott rurális település, nagyjából 70\%-a (1618 fő) magyar. A magyar lakosságon kívül az ukrán etnikum képviseli a megmaradó 30\% (642 fó) nagy részét a faluban. Meg kell említeni viszont, hogy a két meghatározó etnikum mellett a látszólagosan peremhelyzetű, szegregált közösségű cigány kisebbség ugyan kis számban, de jelen van a faluban. Méretét tekintve magyar többségű nagyfalunak számít, mely Kárpátalja nyelvterületei közül magyar nyelvterületen található. Míg a település bürokratikus szellemi elitje még a 2012-2015 közötti intervallumban az ukrán etnikum tagjai közül verbuválódott, ma már magyar a polgármester és a községházán dolgozók nagy része is. 


\section{TANULMÁNY}

Az etnikai megoszlást figyelembe véve mindenképpen érdemes megnézni a falu lakóinak térhasználati jellegét, és magát a térbeli szegregációt az eltérő etnikus közösségek között. A morfológiai szemszögből egy utcás településtípusba tartozó - bár meglehet, hogy több településtípus közé is sorolhatnánk - összesen négy-öt utca által behatárolt falu etnikai térfelosztása sok mindent elárul az együttélésről. Izsnyétén is, mint általában Kárpátalján, „a falvakban a magyar és a ruszin lakosság utcánként különül el egymástól” (Balassa 2003: 25). Már a második terepmunkának interjúztatásai elején kiderült, hogy mentálisan is két falurészt osztottak fel a helybéliek, melyet „oroszvég” és „magyarvég” megnevezéssel láttak el. Egy 86 éves, magyar bácsi például így jellemezte a két etnikai tábor kétfelé osztott elhelyezkedését: „Ốk ott laknak, mi meg itt lakunk, hát laknak itt is oroszok közbe is, ez is orosz család (mutat egy szomszéd házra). Az asszony az itt született. De orosz végesi volt az apja." (86 éves férfi) Mint azt látni lehet, a bácsi térhasználatában döntő szerepet játszanak az emberek közötti viszonyok, az ő esetében a szomszédi kapcsolatok. „A térbeliséget felülmúlhatják a társadalmi kötődések, viszonyok. A távolabb lakó falubéliek, barátok sokkal komolyabb szerepet játszanak a lokális identitás formálásában, mint a közvetlen környezet. A társadalmi kötödések eröteljesebbek lehetnek, mint a territoriálisak." (Keményfi 2004: 20) A későbbiekben, ennek kontextusában egy részletesebb elemzést kíván a társadalmi viszonyok helyzetének leírása.

Fontos találkozási pont a két etnikum tekintetében a községháza, ahol főként a fiatal korosztálybéliek gyakran tartanak rendezvényeket. Izsnyétén mindkét etnikum rendelkezik saját kocsmával, iskolával és templommal, melyek szintén ahhoz a térhez tartoznak, ahol az adott etnikai közösség éli mindennapjait. A faluban két magyar kocsma van és egy ukrán kocsma, ezek is fontos csomópontok a két tér elkülönülésénél. Két iskola van, az egyik magyar tannyelvü, a másik ukrán tannyelvü iskola. Az iskolaház 1850-ben épült fel. Az óvodában még 2013-ban külön egy magyar és két ukrán csoport létezett, ma már csak ukrán csoportok vannak, ide járnak a magyar óvodások is.

A templomok térelhelyezkedése is etnikailag szeparálódik el, ahol az etnikai elkülönülés mellett a felekezeti hovatartozás is meghatározó. A temetők egy adott keskeny úton haladva egymás után bal és jobb oldalon helyezkednek el. Feltűnő, hogy közel a két etnikum térelválasztásánál, tehát nagyjából a főút közepénél, két magánvállalkozó boltja helyezkedik el egymás mellett, melyek közül az egyik bolt tulajdonosa ukrán, míg a másik bolt tulajdonosa magyar nemzetiségű, továbbá felekezetileg is különbözőek. A két bolt tulajdonosainak és családtagjainak jellegzetességeit a későbbiekben kívánom részletezni, itt csak a térválasztás tekintetében jutnak érvényességre. A faluban több magyar bolt található, mint ukrán, tehát a magyar etnikum dominál a település bolti kereskedelmében. További térhasználati jellegzetességek a házakhoz tartozó kapukra készített, általában állatfigura szimbólumok, melyek meggyőződésem szerint, az értékrendek jellegzetességeivel lesznek összefüggésbe hozhatók. 


\section{TANULMÁNY}

A szántóterületek a falu körül, a külső övezetekben helyezkednek el, tehát úgymond körbeölelik a települést. A falu külső gyűrűjén néhány családnak meghatározott méretű, földművelésre alkalmas saját szántóföldje van tulajdonban, vagy bérbe adva. Mivel „az adott tér tudati leképződése a környezeti adottságokon túl függ a társadalom által meghatározott értékrendtől és a kulturális mintáktól is". (Keményfi 2004)

A térbeli megoszlás (etnikumok utcánkénti elkülönülése) árulkodó jel abban a tekintetben, hogy az etnikumok között elhatárolódás, tehát nem egyértelmű asszimilációs folyamatoknak lehetünk tanúi az elmúlt évek kutatásai alapján, hanem inkább szeparálódásnak, izolációnak.

\section{ASSZIMILÁCIÓS FOLYAMATOK IZSNYÉTÉN ÉS KÖRNYÉKÉN}

Kárpátalján az etnikai határátlépések leírása eddig leginkább az asszimiláció elméleti keretében történt. Ez két szempontból is indokolt volt: makroszinten azért, mert a rendelkezésre álló etnikai statisztikák nem tették lehetővé az árnyaltabb megközelítést, míg elméleti szempontból Biczó Gábor érvel meggyőzően amellett, hogy az asszimiláció a kárpátaljai szórványban (is) releváns keretezést nyújt. (Biczó 2004: 85-96)

Kárpátalján 2012 óta kutattunk nagy, legalább 25 fős kutatócsoporttal a Miskolci Egyetem Vizuális és Kulturális Antropológia Tanszék hallgatóival és oktatóival, valamint a Beregszászi Egyetem hallgatóival karöltve. A mindennapi együttélést és kulturális sajátosságokat kutattuk. Disszertációm részeként jelenleg is kutatok, folytattam ezt a kutatást Kárpátalján 2017 óta kutatótársammal, ugyanazokon a településeken, ahol annak idején a kutatócsoporttal kutattunk, de elsősorban a határhoz közel eső Izsnyétén. Az asszimilációs kérdéskör és modell felállítása már 2012-ben felmerült a kutatócsoport kérdései között és a kutatási eredmények révén a modell változott, formálódott.

Az egy helyen élő, de különböző etnikumok együttélési helyzeteinek kutatása az antropológiában főként az asszimilációs és a kulturációs vizsgálatok keretében zajlik. Az asszimilációs folyamatok feltárása etnikai közösségek vagy egyének viszonylatában az együttéléssel járó változás mechanizmusainak vizsgálatát a szociokulturális hasonulás összefüggéseként értelmezi. A kárpátaljai terepegyüttes során is felmerült, hogy mely teóriákat érdemes hasznosítani a kutatás során. Az asszimilációt mint változásfolyamatot az asszimiláló aspektusából a szükségszerűen vállalt konfliktus nyereségeként könyvelik el a kulturális pluralizmus követői, míg az asszimiláns (vagy asszimilálódó) perspektívájából romlásként, veszteségként értelmezték. A Kárpátalján végzett csoportos és részemről egyéni, illetve kutatótársam által végzett előzetes eredmények azt igazolták, hogy az asszimiláció keretfogalomként a kárpátaljai viszonyok leírására csak részben támaszkodhat az ame- 


\section{TANULMÁNY}

rikai társadalomtudományi tradíciókra. Az asszimiláció fogalmát további terminusokkal kell kiegészíteni a vizsgálat során. Ennek oka, hogy a kutatásban résztvevő, kutatott autochton jellegű, tehát hosszú távon együtt elő közösségek együttélési színtere a hosszú távú stratégiákat részben szegregációs és izolációs mechanizmusok sajátos kombinációjaként mutatja be. Az ukrán és magyar fél teljes mértékben szegregálódott egymástól a kutatott években, míg a rendszerváltás utáni évek mást mutattak, izolációs mechanizmusokat. Fontos fogalom a kontaktzóna fogalma a vizsgált térség esetében, melyet be kell ültetnünk a modellbe. A magyar, ukrán és cigány közösség együttélésében a kontaktzónák a település belső etnikai határait jelentik. A kutatások azt támasztják alá, hogy az ukrán, magyar és roma etnikai közösségek érintkezési felületeinek konkrét térjellemzői a kontaktzóna jelentésében elemezhető tulajdonságai a Kárpátalján létrejött együttéléséi gyakorlatoknak.

A két, 2012-2015 között vizsgált faluban (Császlóc és Izsnyéte) az etnikai együttélési helyzet elemezhető az ott élő etnikai közösségek számaránya, mérete, szervezettsége, más szóval a kisebbség-többség reláció eseti formája alapján is. A 2001-es népszámlálás adatai szerint Császlócon a lakosság 828 fó, amelynek 52\%-a (424 fô) magyar, 48\% (404 fő) pedig ukrán nemzetiségű, ami alapján a két etnikai csoport számaránya kiegyenlítettnek tűnik. ${ }^{3}$ Az ukrán családok kisebb része a falu belső terében, döntő többségük azonban a település külső határában felépített tömbházakban él. Ennek megfelelően az adott családok nem csupán fizikailag, de életformájukban is elkülönülnek a magyar népességtől, tehát szegregációról beszélhetünk. A ház körüli kert, gazdasági udvar, vagy jelentősebb földterület hiányában - a kifejezetten agrárjellegű vagy legalábbis komoly mezőgazdasági hagyományokkal rendelkező településen - egyfajta „kvázi urbánus” életvezetési gyakorlat jellemző.

\section{TÖRTÉNETI ÁTTEKINTÉS AZ ASSZIMILÁCIÓ TÜKRÉBEN IZSNYÉTÉN ÉS KÖRNYÉKÉN}

Az asszimilációs folyamatok vizsgálatához a történeti háttér ismeretére van szükség, ezen belül is az ukrán népesség megtelepedésének körülményeire. A történelmi Ungvidék déli részén található falvak (Császlóc, Rát, Kisgejőc, Nagygejőc) a 18. század óta magyar dominanciájú települések voltak, ahol a ruszin és/vagy ukrán lakosság fokozatos betelepedése csupán az 1945 utáni szovjet politikai diktatúra első évtizedeiben vett nagyobb lendületet. Ezzel szemben Izsnyétén az ukrán népesség karakteres közösséggé fejlődése, megtelepedése már a 20. század első negyedében végbement és több generáción keresztül stabilizálódott, amit jól szemléltetnek a településen felvett adatok is (Szilágyi 1997).

\footnotetext{
${ }^{3}$ http://www.ukrstat.gov.ua/ (Letöltve: 2020. 05. 01.)
} 


\section{TANULMÁNY}

A 19. század folyamán a nyelvhatárperemi térségekben a magyar népesség gyarapodásának hátterében a magasabb természetes szaporulata, továbbá a ruszin népesség nyelvi asszimilációja áll. A görögkatolikus ruszinság asszimilációja különösen feltűnő az ugocsai nyelvhatár településein. A városokban - a betelepedés mellett - a zsidóság nyelvi asszimilációja növelte nagymértékben a magyarok arányát különösen Ungváron és Munkácson. A kárpátaljai magyar kisebbségek egészére vonatkozóan elmondható, hogy alapvetően rurális közösségeknek tekinthetők, tehát a városlakók aránya a magyarságon belül mindegyik régióban elmarad a többségi társadalom urbanizáltsági értékeitől. A magyarok többsége tehát itt is falvakban él, akárcsak Szlovákia déli vidékein. A város és falu, tehát urbánus és rurális viszonyok különbségei tekintetében egyértelműen kijelenthető, hogy a szórvány elsősorban városi vagy nagyvárosi jelenség, ahogy arra Szilágyi N. Sándor és Vetési László is rámutat (Szilágyi 1997, Vetési 2014).

Ennek elsődleges oka, hogy a 20. század folyamán az etnikai szerkezet legfontosabb átalakulási folyamatai pont a városokban, megyeszékhelyeken (jelen kutatásunk térségében Ungváron és Munkácson) játszódtak le, mindig az államalkotó ukrán nemzet javára. A nagyvárosokban az államhatalom-váltásokhoz kapcsolódó kivándorlás és lojalitásváltás, valamint a kisebbség-többség relációjában felmerülő aszimmetrikus etnikai reprodukció jelentősen csökkentették a magyarok számát, melyet a magyar tömb falvakból meginduló szocialista urbanizációs folyamatok sem tudtak ellensúlyozni. A rendszerváltást követően a magyarok egyre inkább kisebbségbe kerültek, asszimilációra kényszerültek sok esetben, napjainkra arányuk a legtöbb esetben $20 \%$ alá csökkent.

A 2001 és 2017 közötti becsült csökkenés mértéke természetesen egyenlőtlen mértékű volt. A legjelentősebb tagoló tényező a falu-város különbség. Míg a szórvány falvaiban a csökkenés mértéke 12,5\% volt, addig a városokban ennél sokkal jelentősebb, 21,4\%-os. Mindennek hátterében elsősorban a városokból való kivándorlás nagyobb volumene áll. A másik fontos tényező a magyarok helyi aránya. Míg a 2001-ben 20\% feletti magyar arányú településeken a magyarok aránya 14,3\%-kal csökkent 2001 és 2017 között, addig a 10 és 20\% közötti településeken 10,9\%-kal, a 10\%-nál kevesebb magyart tömörítő településeken pedig 24,4\%-kal. Ezek a számok - bár az arányos összefüggés nem valósul meg teljes mértékben a kis elemszám, valamint egyes kiugró esetek miatt - mégis jól érzékeltetik, hogy minél nagyobb a magyarok helyi aránya, általában annál kedvezőbbek a népesedési adatok körükben (Tátrai 2020: 35-69).

\section{ASSZIMILÁCIÓ IZSNYÉTÉN ÉS KÖRNYÉKÉN}

A demográfiai megközelítés magát a nemzetiségváltást tekinti asszimilációs folyamatnak. A gyakorlatban azonban - kutatási megállapítások, konklúziók is alátá- 


\section{TANULMÁNY}

masztják -, hogy sor kerülhet jelentős mértékű asszimilációra etnikumok között anélkül is, hogy nemzetiségváltás következne be.

Manapság az önidentifikációs változások, illetőleg az asszimiláció szerepe kisebb, mint a 20. században. A 2000-es évek utáni asszimilációs folyamatokat tekintve feltűnő, hogy Kárpátalján a migráció az, amely a demográfiai folyamatok fő mozgatórugója. A magyarok számának folyamatos csökkenése is elsősorban az elvándorlásra vezethető vissza. A 21. században tehát az állandó és ideiglenes migrációs folyamatok azok a jelenségek, amelyek a helyi, főként a falusi települések közösségeit jelentősen lecsökkentik (főként magyar részről). Tátrai és Molnár asszimilációkutatásai, valamint a kárpátaljai szórványtelepülések kutatásai során megállapították, hogy a 2001 és 2017 közötti időszak közel 6000 fős fogyatkozásának mindössze 2\%-át magyarázza az asszimiláció. Sok egyéb ok áll a háttérben tehát a magyarok népességfogyása mellett. A tereptapasztalatok, mindazon felmérések, amelyek teret engednek a többes/köztes identitások deklarálásának, alátámasztják, hogy a többes kötődések és a hibriditás is hasznos megközelítés e terepegyüttesen. A többes kötődés/hibriditás mind egyéni, mind csoportszinten értelmezhető akár az asszimilációs folyamat lépcsőfokaként, állomásaként, de még jellemzőbb, hogy az egyén ebbe az identitásba természetes módon beleszületik, beleszocializálódik (Tátrai 2020: 50-54).

Az asszimiláció és hibriditás társadalomtudományi fogalmai és adott terepegyüttesen lezajló társadalmi folyamatai ugyancsak más mintákat produkálnak a vizsgált Császlóc és Izsnyéte lokális településeken a városokhoz és más etnikai összetételű, határ menti kárpátaljai településekhez képest, már korai terepbejárásoknál láthatók voltak az etnikumok közötti elkülönülések különböző formái, így más terminusok bevonásai is meghatározók lehetnek.

\section{Asszimilációkutatás Izsnyétén}

\section{A TEREPKUTATÁS KÖRÜLMÉNYEI, NEHÉZSÉGEI ÉS ELŐNYEI}

A 2017-től kezdődő terepmunkát, általános gyűjtőmunkát és irodalmi kutatómunkát nagyban megkönnyítette számomra, hogy Kárpátalján 2012-2015 között is kutattam nagyobb kutatócsoporttal. Így több száz fős korábbi minták összevetésével tudok dolgozni, amelyek előrelendítik a kutatást és összehasonlítást a szinkronikus kutatásokkal. A nagy minták ugyanakkor nem jelentenek egyértelműen reprezentatív mintát, ugyanakkor megkönnyítik a további kutatásokat, illetve egyfajta longitudinális társadalomtudományi kutatást is szül, hiszen a terepen több év távlatában tudok kutatni, összehasonlítva több év különbségével a változásokat, változó jelenségeket, tendenciákat. További előny, hogy a különböző kárpátaljai kutatások alkalmával több módszert is tudtam vagy kutatócsoporttal együtt tudtunk alkalmazni, így 


\section{TANULMÁNY}

kérdőíves vizsgálatokat, filmfelvételeket, résztvevő megfigyelést, mélyinterjúkat, illetve asszimilációkutatást.

A nehézségeit itt is - ahogy a felvidéki kutatások esetében is - elsősorban a koronavírus világjárvány okozta, mely megnehezítette a terepekre való többszöri kiutazást, az interjúalanyok személyes felkeresését, de általánosságban véve az egész kutatásra nagy, negatív hatást gyakorolt, lassította, akadályozta azt. 2014 után az ukrán-orosz harcok és háborús helyzet miatt nem tudtunk kutatócsoportban kutatni tovább, a megkezdett kutatások abbamaradtak, részemről az asszimiláció és megélhetési stratégiák témaköre, ezt próbáltam a 2017-es év utáni években pótolni, folytatni a teljesség igénye nélkül. 2020-ban a megélhetési stratégiák témakörét kutatva lassított a koronavírus járvány, a kárpátaljai terepre nagyon nehezen jutottam ki, körülményes és nem a szokványos módon tudtam megkérdezni embereket, nehéz volt a résztvevő megfigyelés módszerének alkalmazása is, sőt inkább lehetetlen. Több interjú online, vagy telefonon lett felvéve, a krízis fóként az asszimilációkutatást érintette. Ugyanakkor szép számban születtek adatok és korábbi kutatásaimból is tudtam táplálkozni, hogy az asszimilációkutatást eredményesen hajtsam végre.

\section{AZ ADATKÖZLŐK CENZUS ADATAI}

A strukturált interjúk adatfeldolgozásánál 113, elsősorban magyar nemzetiségű izsnyétei lakos (a település egészének 5,3\%-a) került a mintába, de több esetben vegyes házasságban élőkről volt szó, így 5 ukrán nemzetiségű lakossal is készült adatfelvétel tolmács segítségével a beregszászi egyetemről. Izsnyétén az idősek aránya nagyfokú, így 80\%-ban idősekkel készültek az interjúk, főként, hogy a kutatások hétköznapokon zajlottak le, amikor a fiatalok nem tartózkodtak otthon, mert munkában voltak. Az online felmérés azonban elősegítette, hogy nagy számban kerüljenek a fiatalabb generációból is válaszadók a mintába. Mivel a válaszadók $80 \%$-ban idősek voltak, így aktív munkavállalás, vagy munkaerőpiaci helyzet tekintetében 80\%-uk nyugdíjas volt, és a 20\%-ban található munkavállaló vagy gyesen, gyeden lévő asszony, illetve tanuló, vagy elenyésző munkanélküli is.

\section{STRUKTURÁLIS VAGY NYELVI ASSZIMILÁCIÓ}

A megkérdezett 113 adatközlő közül 111-en beszélnek anyanyelvi vagy tökéletes szinten magyarul és csak ketten tartoznak az „elég jól beszéli a magyar nyelvet” csoportba. A megkérdezettek közül 32-en tökéletes szinten, 36-an elég jól, 34-en kicsit és 11-en egyáltalán nem beszélik az ukrán nyelvet. Ebből az derül ki, hogy anyanyelve mellett a megkérdezett magyarok többsége egy megfelelő szinten tud beszélni ukránul is. 


\section{TANULMÁNY}

1. táblázat. Nyelvhasználat Izsnyétén (\%)

\begin{tabular}{|c|c|c|c|c|}
\hline Nyelv & $\begin{array}{c}\text { Anyanyelvi/ } \\
\text { tökéletes szint }\end{array}$ & $\begin{array}{c}\text { Elég jól } \\
\text { beszéli }\end{array}$ & $\begin{array}{c}\text { Kicsit } \\
\text { beszéli }\end{array}$ & $\begin{array}{c}\text { Egyáltalán } \\
\text { nem beszéli }\end{array}$ \\
\hline Magyar (\%) & 98 & 2 & 0 & 0 \\
\hline Ukrán (\%) & 28 & 32 & 30 & 10 \\
\hline
\end{tabular}

Forrás: Saját szerkesztés

A kulcs adatközlők nyelvhasználatról szóló elmondásaik alapján kiderült, hogy a leggyakrabban használt nyelv a magyar nép családi körében továbbra is a magyar nyelv, munkahelyen az ukránt, régebbi időkben az orosz nyelvet volt szükséges használni a hatékony munkavégzés szempontjából. Az idősebb korosztály még az orosz nyelvet tanulta főleg a helyi iskolában, manapság már a fiatalok beszélik jobban az ukrán nyelvet. Ennek az az oka, hogy több magyar anyanyelvú szülő tartja úgy, hogy ha magyar nyelvü gyermekét ukrán iskolába járatja, akkor az növeli a továbbtanulási és munkahelyen való elhelyezkedési esélyeit, hiszen a közép- és felsőfokú ukrán állami intézményekben az ukrán nyelv használata elsődleges, továbbá az állami munkahelyek esetében is ugyanez az elvárás mutatkozik. Televízióból, újságból és rádióból, tehát a tájékozódás és információgyűjtés szintjein a magyarok a legtöbb esetben magyar nyelvű adásokat néznek, magyar nyelvű újságokat olvasnak, és magyar rádióadást hallgatnak.

Nyelvhasználattal kapcsolatos konfliktusok látszólag nincsenek a faluban, a rejtett etnikus elhatárolódás inkább a térbeli szegregáció és a vallás szintjén jelentkezik. „Az etnikai konfliktusok humán ökológiai elemzési módszereinek egyike az ún. versenyelméleti magyarázat szerint, az etnikai konfliktusok valószínüsége akkor csökken a minimumra, amikor a csoportok életterei nem fedik egymást. Az egymás kiszorítására való törekvés elősegíti a konfliktusok kiéleződését és a területi szegregációt is." (Keményfi 2004: 163)

Konfliktusokat urbánus jellegű területeken említenek, például Munkács esetében, vagy hivatalos helyeken inkább, ahol már elvárják a másik, tehát az ukrán nyelv ismeretét és használatát, de a konfliktusok a régebbi időkben voltak jellemzőek, ma már nem övezik konfliktusok a jelen kapcsolatokat. Leggyakoribb konfliktusgerjesztő forrás a szomszéd falu, Gorond fiataljainak szórakozás céljából Izsnyétére való látogatása, amikor is illuminált állapotban kerülnek összetűzésbe a helybéliekkel, de ebben az esetben sem elsősorban a nyelvhasználati eltérés, vagy az identitás mássága a támadás oka. Egy 57 éves nő így vélekedik a tisztán ukránok lakta Gorond lakóiról: „Ez olyan vérengző nép, ez a gorondi!"(57 éves nő) A hivatalos ügyeket egyébként teljes mértékben ukrán nyelven intézik. A falusiak eljárnak mind az ukrán, mind a magyar boltokba egyaránt, ezeken a helyeken sem az etnikai különbözőségek a meghatározóak, inkább a materiális és fiziológiai, tehát az alapvető szükségleteik. Tehát, amelyik árucikk az egyik boltban nincs, azért a másik, akár ukrán, akár magyar bolt- 


\section{TANULMÁNY}

ba mennek el beszerezni, függetlenül a bolt tulajdonosának nemzetiségétől. Egyik adatközlő kiemeli, hogy az ukránok boltja több esetben olcsóbb termékeket kínál, ezért oda gyakrabban elmennek vásárolni, ez esetben tehát a jövedelmi helyzet, kereslet-kínálat viszony is fontos aspektus a bolti látogatásoknál.

Releváns megemlíteni a nyelvi asszimiláció egy fontos hatását, eredményét. Az évszázadok során több nemzet közigazgatásához is tartozó és ezáltal vegyes ajkúvá váló mezorégió kialakított egy bizonyos nyelvi keveréket, amelyet a helyiek „kárpátaljasi" nyelvnek neveznek, melyet Izsnyétén leginkább az idősek köreiben használnak. Ez az úgynevezett ősnyelv, régi nyelv, melyben számtalan, főként szláv nyelvi eredetű szavak, kifejezések keveredése lelhető fel. Így mutatja be a kevert, „kárpátaljasi” nyelvet egy 58 éves, ukrán nő: „Az minden, össze van keverve. Szlovák, lengyel, cseh, német, magyar, román. Abba mindenféle nyelv van keverve. Az a régi nyelv. Kárpátaljasi." (58 éves nő)

A településen élő roma családok kutatási adatait figyelembe véve megállapítható, hogy a romák a kizárólag magyar nyelvet beszélő izsnyéteiek közé tartoznak, hivatalos helyeken rá vannak kényszerítve az ukrán nyelvre. Izsnyétén a romák hivatalos ügyeinek intézése során egy olyan stratégiát folytatnak a nyelvi akadályok leküzdése gyanánt, hogy aki közülük tud ukránul, őt küldik, vagy ővele mennek ügyintézni, hiszen többségük nem beszél ukránul.

\section{VEGYES HÁZASSÁG ÉS ASSZIMILÁCIÓ}

A vegyes házasságok elemzéséhez a SUMMA 2017 nevü feméréseket vettem alapul, melyek széles spektrumban vizsgálták Kárpátalján a vegyes házasságokat. Jelen tanulmányban vegyesnek tekintjük azokat a házasságokat, ahol a házastársak nemzetisége eltér, vagy valamelyikük kettős identitású. Vegyes család pedig az, amelyben van a többiektől eltérő nemzetiségü, vagy kettős identitású családtag.

A 2001-es népszámlálás 10\%-os mintája - mely nem reprezentatív - alapján a házas magyarok 16\%-a élt nemzetiségileg vegyes házasságban egész Kárpátalján. (Tátrai 2020)

Az etnikailag heterogén házasságok gyakorisága jelentős változékonyságot mutat Kárpátalja közigazgatási egységeiben. A magyar tömb járásainak falusi területein a magyarok mindössze 7-15\%-a élt vegyes házasságban. Ezzel szemben a nyelvhatár városaiban a vegyes házasságban élő magyarok aránya a magyarok körében jóval nagyobb - Ungváron 59\%, Munkácson 42\%, Huszton 43\% -, ami összhangban volt azok nemzetiségi összetételével is (Tátrai 2020).

Az adatokból az látszik, hogy a vegyes házasságok inkább az urbánus területeken jellemzőek, ezt az is indokolhatja, hogy számos kistelepülésen, faluban térbeli elkülönülés jellemző az etnikumok között. Izsnyétén azonban a térbeli elkülönülés ellenére is meglehetősen magas a vegyes házasságban élők száma. 


\section{TANULMÁNY}

Izsnyétén az egész kárpátaljai, főként magyarok lakta vidékekhez hasonlítva a vegyes házasságok aránya kiemelten magas. Párválasztásnál nincsenek eltérő párválasztási szokások, sőt egyre jellemzőbb a nők körében, hogy magyar férfit választanak maguknak párjuknak. A megkérdezettek közül 57\%-ban élnek vegyes házasságban Izsnyétén.

\section{VALLÁS ÉS ASSZIMILÁCIÓ}

A falu etnikumainak térbeli elkülönüléséhez nagyban járul hozzá a felekezeti elkülönülés, eltérés is. Az eltérő vallási felekezethez tartozás egyértelműen etnikai kötődést jelöl, tehát a magyar nemzetiségűek szinte minden esetben a református egyház tagjai, míg az ukrán nemzetiségűek pravoszlávok, egy részük görögkatolikus vallású. Ezt alátámasztják a kérdőíves felmérés kvantitatív adatai is, miszerint a megkérdezett 113 izsnyétei magyar közül 95-en reformátusok, csupán 5-en görögkatolikusok, 11-en egyéb vallások hívei és ketten nem tartoznak egyik egyházi felekezethez sem. A görögkatolikusokat Kárpátalja-szerte a reformátusok és a római katolikusok egyaránt „oroszoknak” mondják. A legtöbb helyen azonban kifejezetten a vallási hovatartozásukra vonatkoztatják ezt, és „régi, jó magyar családoknak” tartják őket (Pilipkó 1995).

Az, hogy a vallás mennyire határozza meg az etnikus értékrendet, mi sem mutatja jobban, mint hogy a 'reformátust' a 'magyar', a 'pravoszlávot' pedig az 'ukrán' megnevezés szinonimájaként említik.

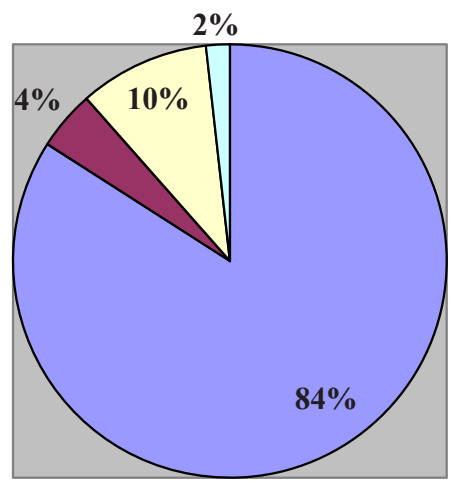

\begin{tabular}{|l|}
\hline$\square$ Református \\
$\square$ Görög-katolikus \\
$\square$ Egyéb \\
$\begin{array}{l}\square \text { Nem tartozik egyházi } \\
\text { felekezethez }\end{array}$ \\
\hline
\end{tabular}

1. ábra. Felekezeti hovatartozás Izsnyétén (\%)

Forrás: Saját szerkesztés

A saját vallási ünnepek megtartása kapcsán figyelemreméltó eredmény tűnik ki a kérdőíves adatokból, miszerint a nagyrészt református vallást követő hívek közül csupán 38 családban tartják meg a vallási ünnepek többségét. Az eltérő felekezetek 


\section{TANULMÁNY}

tagjainak egymás egyházi alkalmainak látogatása leginkább azon családok körében intenzív, ahol vegyes házasságban élnek és a házasfelek eltérő felekezethez tartoznak. Megfelelően támasztja alá ezt egy 62 éves ukrán nő arra a kérdésre válaszolva, hogy látogatja-e más felekezetek egyházi alkalmait: „A reformátusokat igen szoktam, mikor áldoznak, mikor az ünnep, mert tartjuk a református ünnepeket, mindent megünneplünk. A rokonok jönnek nálunk, mi is szoktunk oda, na, ellátogatni." (62 éves nő) Viszont a temetési alkalmakon részt vesznek az emberek, függetlenül attól, hogy kinek, milyen vallási keretein belül zajlik a temetési szertartása. Itt a rokoni és baráti kapcsolatok a meghatározóak. Felekezetválasztás vagy váltás tekintetében az etnikum a meghatározó, így elkülönülés jellemző, míg a vallási ünnepek megtartásánál nem a felekezeti hovatartozás a mérvadó.

\section{MIGRÁCIÓ ÉS ASSZIMILÁCIÓ}

Az izsnyétei lakosság körében is nagyon jellemző, nagymértékű az elvándorlás, a migráció, ugyanakkor leginkább az ideiglenes migráció köthető leginkább az izsnyétei lakosok migrációs stratégiáihoz, akár magyarokról, akár ukránokról beszélünk.

Az asszimilációkutatás adataiból kirajzolódik, hogy a vizsgált 113 személy (5,3\%) közül 38-an jártak már külföldön ideiglenes vagy tartós munkavállalás céljából, ebből 36-an Magyarországon, ketten Oroszországban és egyetlen személy Romániában. A külföldre utazás célja elsődlegesen rokonlátogatás volt, ezt követi a munkavállalás, majd a hivatalos ügyintézés, az üdülés, a vásárlás és a továbbtanulás. Mivel a kvantitatív adatok ritka esetben voltak fiatal korosztálybeliek, és mint ismeretes, inkább a fiatal korosztály érintett a külföldi migráció tekintetében, így előnyös megemlíteni, hogy a vizsgált 113 háztartásból 84 esetében vannak családtagjaik, leginkább a válaszadók gyermekeinek generációjában, akik a megkérdezés időpontjában is külföldön tartózkodtak, legtöbb esetben munkavállalás céljából.

Az utóbbi időkben megnőtt a nyugati országokba való egyre intenzívebb vándorlás is, mind a magyarok, mind az ukránok körében. Mivel a migráció az izsnyétei lakosok tekintetében elsődlegesen ideiglenes migráció, így nem okoz sok fennakadást az otthoni együttélés, illetve változást az asszimiláció tekintetében. Ez lokálisan nem hat ki az asszimiláció folyamatára, azonban a térség, a határ menti magyar települések, fóként városok elvándorlási hullámait tekintve a magyarok nagyobb arányban vándorolnak el, tehát az asszimiláció e tekintetben az ukránok irányába mutat helyben. A magyarok fiatal generációi más országok, fóként nyugati országok (köztük Magyarország is) kultúrájának, közösségének tagjaivá válnak, ott asszimilálódnak. 


\section{TANULMÁNY}

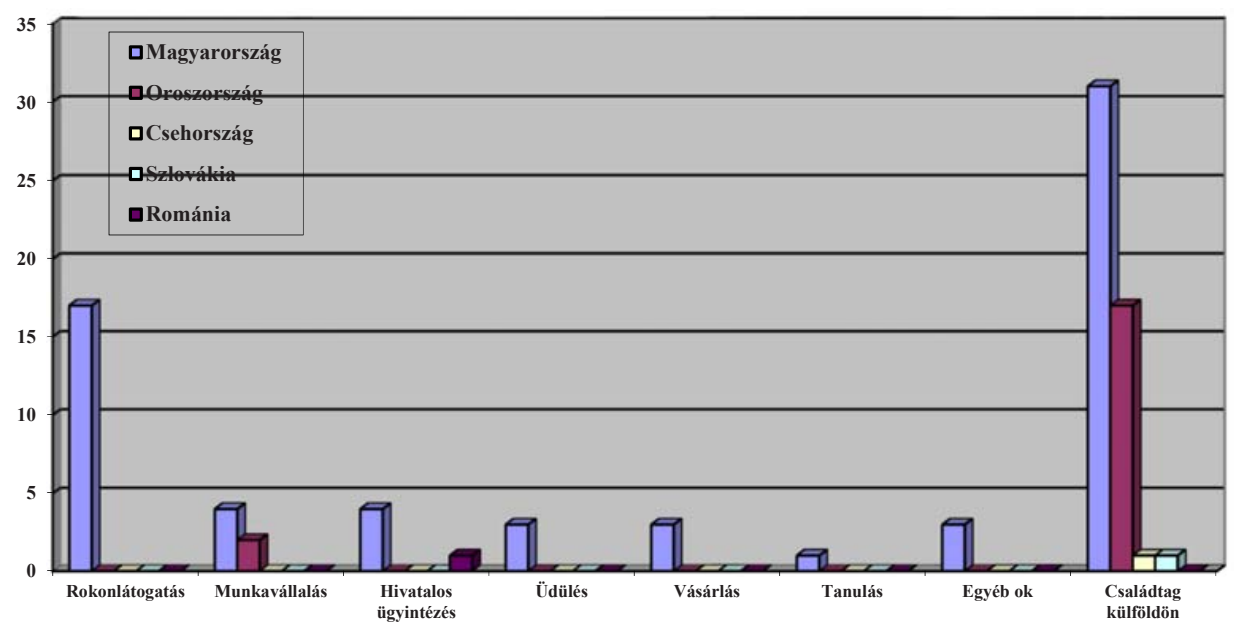

2. ábra: Migráció Izsnyétén

Forrás: Saját szerkesztés

\section{Összegzés}

2015-ben az antropológiai kutatócsoport adatai alapján megállapítottuk, hogy az Izsnyétéhez közel eső Császlóc egy kétpólusú település. A későbbi kutatások eredményei révén Izsnyétén azonban egy multietnikus (magyar, ukrán, roma) együttélési szituációt különböztethetünk meg.

Eltérő társadalomtudományi modellt állíthatunk fel a két településen. A felsorolt formális szempontok alapján az etnikai együttélési helyzetek nagyon eltérő formákat ölthetnek, amelyek a lokális szintér keretei között eltérő kapcsolatminőségek kialakulásának feltételeit képezik, s ily módon kiemelkedő szerepet játszanak az etnikai transzferek értelmezésében is. Császlócot és Izsnyétét eltérő együttélési modellek jellemzik, azonban a vizsgált két határon túli település együttes, vagy települések között még inkább eltérő együttélési, asszimilációs modelleket különböztethetünk meg, vagy azonosíthatunk.

Az elkülönülés, az izoláció jellemzi tehát leginkább Izsnyéte etnikumainak együttélését. Ezt az elkülönülést mindhárom társadalmi csoport elfogadja és fenntartja. 


\section{TANULMÁNY}

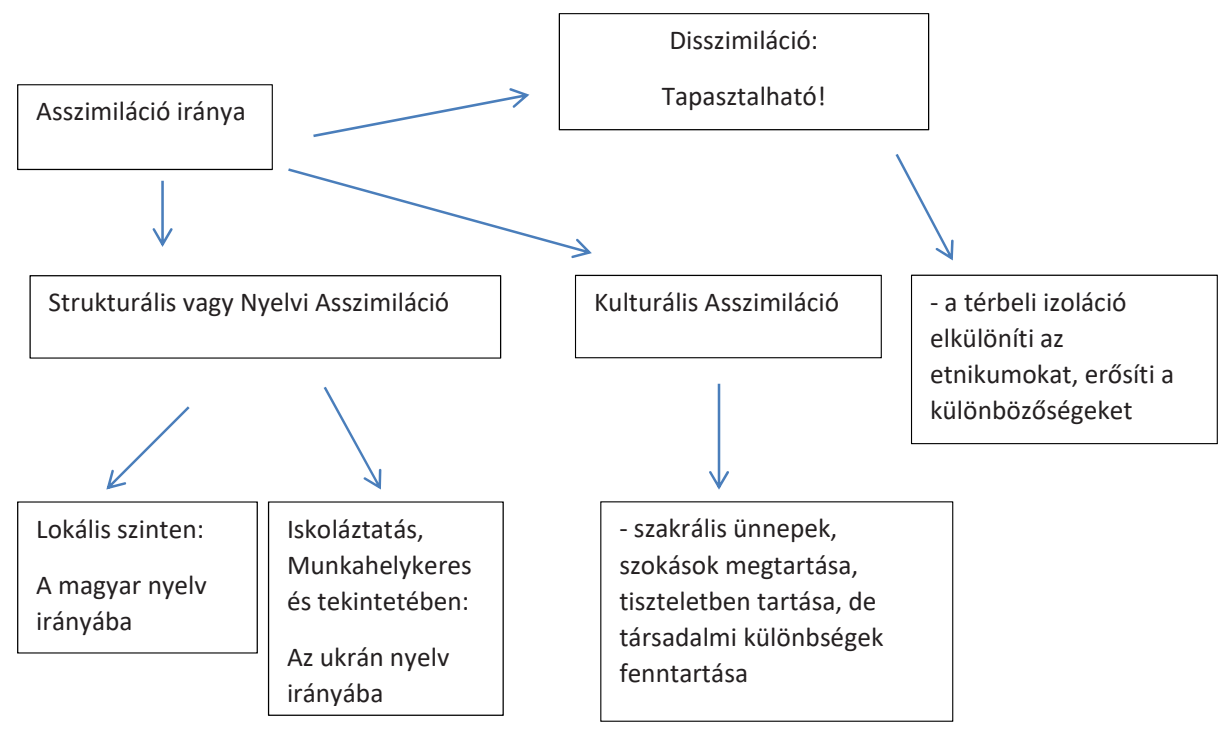

3. ábra: Az izsnyétei közösség asszimilációjának iránya Forrás: Saját szerkesztés

Az asszimilációelméletek tükrében az izsnyétei multietnikus településen az izoláción kívül egy mélyebb jelentéstartalommal rendelkező modellt, a disszimilációt ültethetjük be, hiszen a disszimiláció irányába mutatnak a változásfolyamatok. Bár további kutatások szükségesek az eredmények alátámasztására, a két kárpátaljai település etnikus együttélési modelljei különbözőek, Izsnyéte közössége sokkal inkább elkülönül egymástól a mindennapi találkozások gyakorlatában, és a különböző, a tanulmányban is vizsgált asszimilációt meghatározó tényezők fényében.

A vizsgált etnikumok együttélésére az elkülönülés, a társadalmi különbségek fenntartása a jellemző, ezért egyértelműen disszimilációs folyamatról beszélhetünk a vizsgált településen a szinkronikus kutatások eredményeiből következtetve, mely terminus a legközelebb áll a lokális közösség együttélési jellemzőinek leírására, magyarázatára. Természetesen e tézis megerősítésére, alátámasztására további vizsgálatok, személyes terepkutatások szükségesek a jövőben. 


\section{TANULMÁNY}

\section{Irodalom}

Balassa I. (2003): A szomszédos országok magyarjainak néprajza. Budapest, Planétás Kiadó

Baranyi B. (2009): Kárpátalja. Pécs - Budapest, Dialóg Campus Kiadó

Barth F. (1996): Régi és új problémák az etnicitás elemzésében. Regio. 7. évfolyam 1. szám

Biczó G. - Kotics J. (2013): „Megvagyunk mi egymás mellett”. Magyar-román etnikai együttélési helyzetek a szilágysági Tövisháton. Miskolc, ME KVAI és Csokonai Kiadó

Biczó G. (2004): Asszimilációkutatás - elmélet és gyakorlat. Budapest, Osiris

Biczó G. (2014): Az asszimiláció, a kontaktzóna és az interkulturalitás néhány elméleti kérdése a kárpátaljai etnikai együttélési helyzetek vizsgálatában. Szellem és tudomány, 1. szám, 85-96.

Borbély S. (2013): Kompenzációs mechanizmusok és egyensúlyteremtő stratégiák egy vegyes (magyar-roma) etnikai összetételű határvidéki településen. Erdélyi Társadalom - 14. évfolyam 1. szám, 22.

Fedorenko N. P. (1984): A szocialista országok gazdasági mechanizmusa. Budapest, Közgazdasági és Jogi Könyvkiadó

Fodor Gy. (2003): Kárpátalja demográfiai jellemzése a népszámlálások adatainak tükrében. In: Süli Zakar I. (szerk.): Társadalomföldrajz - Területfejlesztés I. Debrecen, Kossuth Egyetemi Kiadó

Karády V. (1997): Zsidóság, polgárosodás, asszimiláció. Tanulmányok. Budapest, Cserépfalvi

Keményfi R. (2004): Földrajzi szemlélet a néprajztudományban: etnikai és felekezeti terek, kontaktzónák elemzési lehetôségei. Debrecen, Kossuth Egyetemi Kiadó

Molnár J. (Молнар Йосип) (2016): Національна ідентичність нащадків етнічно змішаних (українсько-угорських) закарпатських родин за даними перепису населення та анкетного опитування. In: Berghauer S. (szerk.): Social Geographical Challenges and Search for Adequate Answers in East-Central Europe of the 21st Century. Berehove, Ferenc Rákóczi II Transcarpathian Hungarian Institute, 166-174.

Niedermüller P. (1999): Etnicitás és politika a késő modern nagyvárosban. Replika, 38. szám, 105-120.

Pikler K. (2016): Az EU területi statisztikai rendszere (NUTS). Tér és Társadalom, 30. évf., 2. szám, 29.

Pilipkó E. (1995): Etnikai és vallási identitás a salánki görög-katolikusok körében. Budapest, Ethnographia 


\section{TANULMÁNY}

S. Benedek A. (1994): Kárpátalja története és kultúrtörténete. Budapest, Bereményi Könyvkiadó

Smith, Seymour (ed.) (1993): Dictionary of Anthropology. London, Macmillan

Szilágyi N. S. (1997): A szórványmagyarság: probléma vagy ürügy? In: Szilágyi N. S. (szerk.): Miegymás. Kolozsvár, Kalota Kiadó, 476-493.

Szuhay P. (1999): Foglalkozási és megélhetési stratégiák a magyarországi cigányok körében. In: Kemény I. (szerk.): A cigányok Magyarországon. Budapest, MTA, 23.

Tátrai P. - Molnár J. (2020): Az asszimiláció helye a kárpátaljai szórvány népességfejlődésében, recens demográfiai jellemzőiben. Regio, 1. szám, 35-69.

Yinger, J. M. (1976): Ethnicity in complex societies: structural, cultural, and characterological factors. In: Coser, L. - Larsen, O. (eds.): The Uses of Controversy in Sociology, Free Press, New York, 197-216.

\section{Elektronikus források}

https://www.arcanum.hu/hu/online-kiadvanyok/Lexikonok-a-magyar-nyelv-ertelmezo-szotara-1BE8B/sz-4A3C0/szorvany-4CE29 (Letöltve: 2020. 10. 08.)

http://www.karpatalja.ma/karpatalja/szines/9208-husveti-paszkaszenteles (Letöltve: 2020. 01.10.)

http://www.kislexikon.hu/magyar_a_a_a_a.html (Letöltve: 2019.09.11.)

Az ukrán népszámlálás hivatalos honlapja: http://www.ukrcensus.gov.ua (Letöltve: 2019. 10.15.)

http://www.ukrstat.gov.ua/ (Letöltve: 2020. 05. 01.)

http://www.karpataljaturizmus.net/telepules.html (Letöltve: 2019. 11.10.)

http://mek.oszk.hu/02100/02115/html/4-966.html (Letöltve: 2020. 01. 10.)

https://mek.oszk.hu/02200/02201/02201.htm\#7 (Letöltve: 2020. 01. 10.)

https://idegen-szavak.hu/izol\%C3\%A1ci\%C3\%B3 (Letöltve: 2020. 01. 10.) 